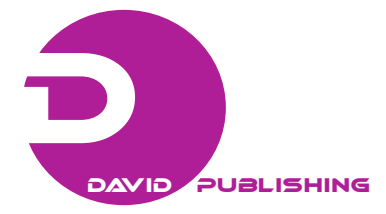

\title{
Cairo's Slums: A Ticking Time Bomb
}

\author{
Abdul-Wahab El-Kadi \\ College of Engineering and Technology, Arab Academy for Science and Technology and Maritime Transport, Cairo 11311, Egypt
}

\begin{abstract}
Despite being one of the symbols of civilization throughout human history, Greater Cairo has many slum areas, hosting a population of three million people living in deteriorating conditions and lacking the basic human necessities. These slums represent a fertile environment for diseases caused by pollution in all its forms and are subject to crimes, rape and theft. There is a huge difference in the state of conditions when comparing the formally planned areas to the informally planned ones. People living in the formally planned settlements, like Nasr City, and in informal ones, like Ezbet El-Haggana, are similar to the kings and queens and slaves of legends. This paper tries to find solutions to the problem of slums and random areas.
\end{abstract}

Key words: Cairos' slums, Cairo's informal settlements, reallocation of Cairos' slums, development of Egypt's corridor.

\section{Introduction}

The UN (United Nations) defines the house any person should have as a dwelling and a healthy place, which could provide them with shelter and give them minimum dignity. From the authors' point of view, unprivileged people should not have to ask for their rights; they should also not attempt to obtain their rights illegally, if they could not get them by legal means. This paper gives a prescription of slums in Cairo. From the author's point of view, reallocation is the best solution to such an issue in Cairo. This paper does not aim to solve the problem of each individual slum but aims to solve the problem of slums and random areas as a whole as it is a national, important and urgent matter that needs a scientific solution rather than a temporary one that makes matters worse in the future [1].

\subsection{The Concept of Slums}

Slums are areas that are constructed by the individual people, usually immigrants from villages, who came to big cities looking for better jobs [2]. These houses are usually built on private areas or on usurped state lands without a system and without

Corresponding author: Abdul-Wahab El-Kadi, Dr., research field: architecture engineering. E-mail: amadelelkadi@hotmail.com. licenses or planning.

Slums consist of buildings lacking healthy ventilation and appropriate lighting. In addition, the buildings themselves do not comply with rules of buildings and housing in terms of heights and provision of facilities shown in Fig. 1.

Slums are a heterogeneous urban fabric, consisting of unauthorized housing in disadvantaged areas in terms of public utilities and basic services. Slums vary in their forms and manifestations and had initially spread on the borders of cities, then gradually leaked out to the suburbs (Fig. 2).

It is clear that the housing areas are random groupings that arose in the absence of general planning of cities, and apart from the laws of farmland protection, encroachment on state property, individuals are therefore deprived of all kinds of facilities and basic services of water, sanitation and electricity.

\subsection{Types of Slums}

(1) Degraded areas

They are neighborhoods that were located in good condition, but deteriorated later. They may also be areas that became overcrowded and were leased to low-income people;

(2) Slums

They are poor areas in terms of the quality of 


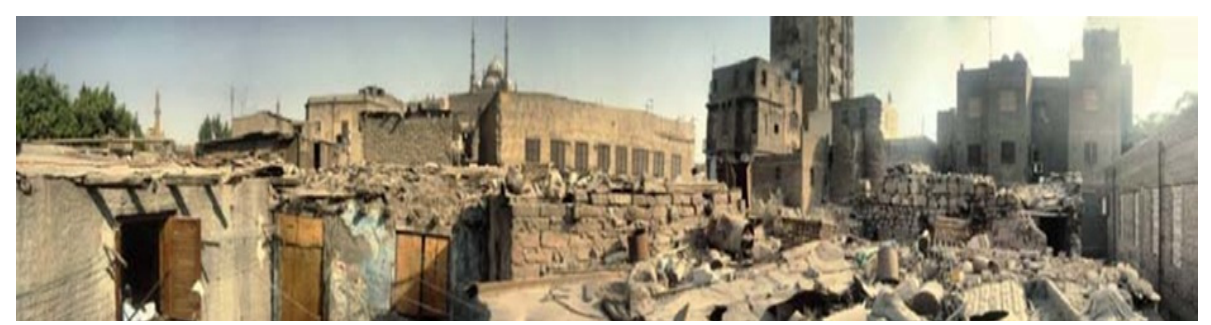

Fig. 1 The poor condition of districts in slums.

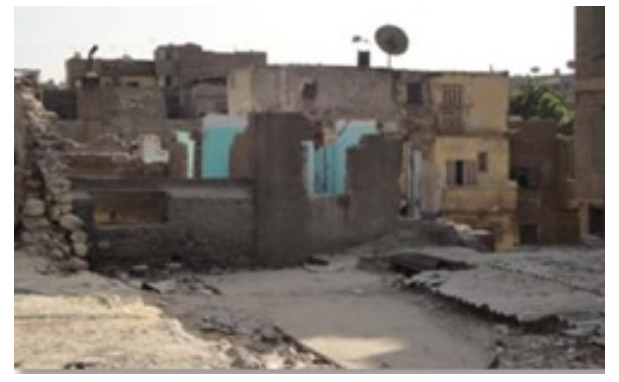

Fig. 2 Slums conditions.

housing. The built houses on land are infringed upon illegally. They are also called shantytowns (Fig. 3);

(3) Illegal partition areas

They are areas where the legal landowners divided the land into smaller pieces and sold or leased them without following the rules.

\subsection{The Emergence of Slums}

Numerous planning experts assert that the spread of slums in Egypt began with the beginning of the 20th century as people began migrating from rural areas to the bigger cities and due to people not complying with the Ministerial Decree No. 28 of 1914.

This migration led to the transformation of such areas into slums and shantytowns lying on the outskirts of cities. Slums were formed due to the lack of supervision during the second half of the twentieth century and due to an increase in population resulting from the migration. Most of the slum land is desert land owned by the state or agricultural land in which unofficial divisions were made and houses were erected.

\subsection{Reasons behind the Spread of Slums}

The problem of slums began at the beginning of the twentieth century with the rapid urbanization of major cities in Egypt, and with the availability of job opportunities in these cities because of the concentration of government departments or because of the emergence of many modern industries.

This has led to an increase in internal migration of individuals from the countryside to the cities in pursuit of better jobs, as investors prefer to establish their projects in areas near Cairo and Alexandria (Fig. 4).

The countryside immigrants seek to get adequate housing in the periphery of cities, where housing costs less especially if they lack services.

The state was not alert about the seriousness of the problem and did not take any actions to confront it since its beginning.

Those areas are built against the law, so the state authorities refuse to provide them with services such as

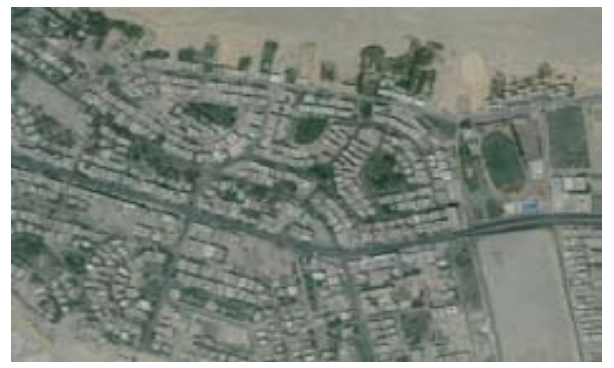

(a) The patterns that surrounded slums area

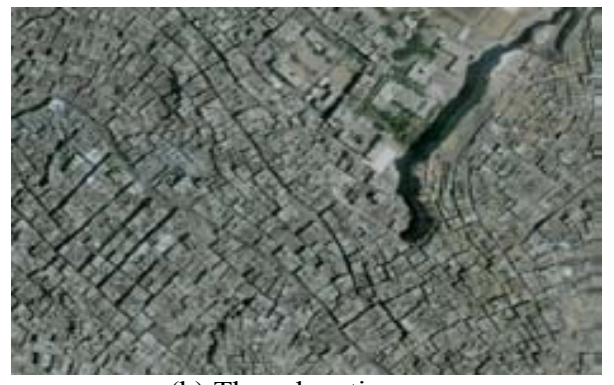

(b) The urban tissue

Fig. 3 The big difference in planning between slums and formally planned area how the urban pattern differs between both (Mansheyet Nasser-Al-Mokattam). 


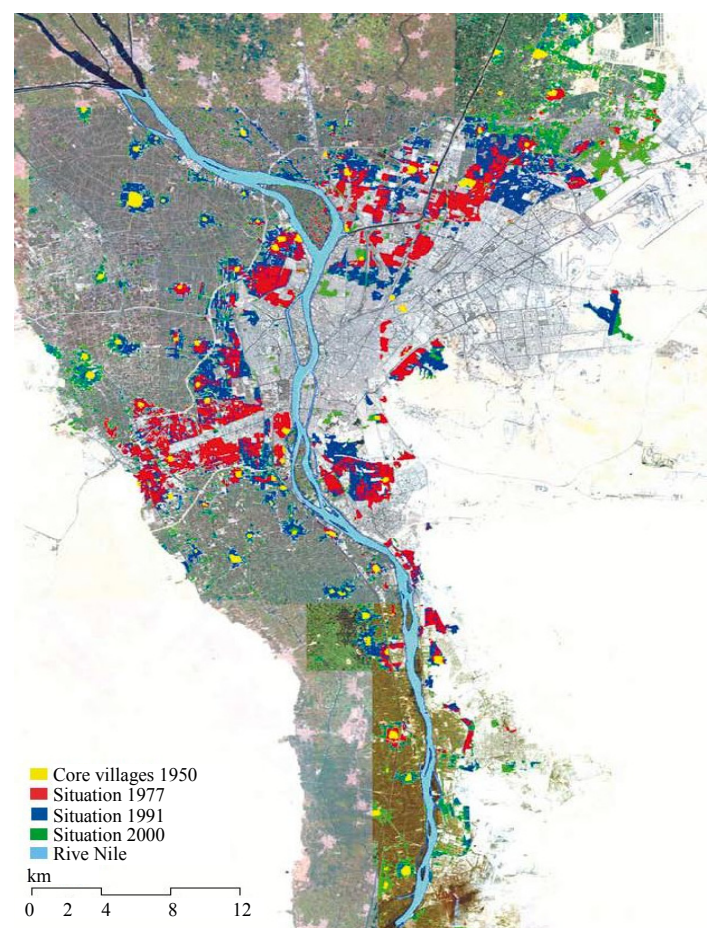

Fig. 4 The locations of Cairo slums and their growth since 1950 [3].

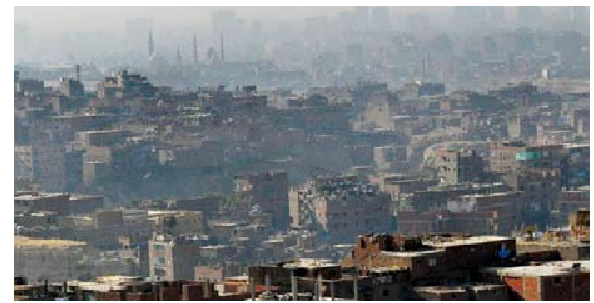

Fig. 5 The slums extension around Cairo [3].

water, sanitation or electricity, as well as building schools and medical centers. Thus, unplanned slum areas began, lacking sanitation as well as the necessary services of normal life (Fig. 5).

One of the factors that lead to the emergence of slums is the fusion of urban villages. As the population and the need for housing increased, people began building on farmlands, which led to expanding unplanned villages and thus creating more slums and random areas.

\subsection{Why We Need to Develop Slums}

The reasons are as follows:

- Provision of housing should be at all levels of society for all classes;

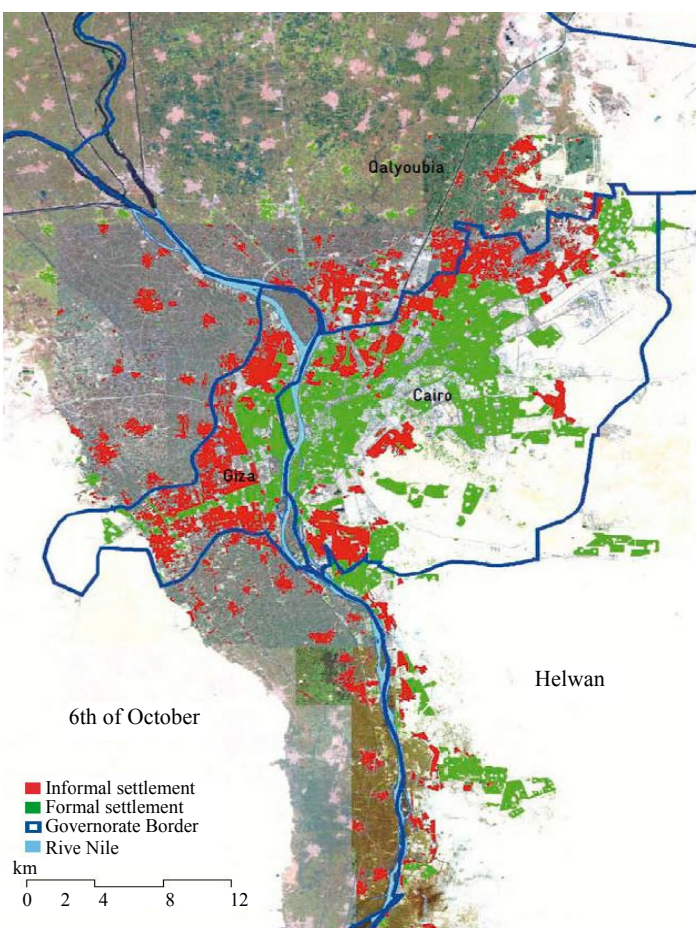

- Avoiding the emergence of diseases;

- To decrease the absence of the state and the deliberate violation of laws.

\subsection{Means to Solve the Problem of Slums}

In order to deal with the needs of poor, communities need to understand how these people live and the problems they face:

- Changing the vision of various countries regarding slum areas must be done so that people living in slums can be included as communities on a high degree of regulation both spatially and socially;

- Occupants of those areas should be actively involved in the development of the urban economy;

- Some slums represent local economies, land markets and informal housing;

- Because of the diversity of slums, both governmental and non-governmental organizations have to understand the characteristics of slums through a comprehensive inclusive vision;

- Slum dwellers have a better knowledge of how to work in their communities, along with their needs and 
priorities; therefore, they can be considered the clue in developing their areas.

\subsection{Alternatives to Deal with Slums}

\subsubsection{Forced Evictions and Slum Clearance}

Forced evictions without providing alternative places to resettle the population constitute a serious violation of human rights.

These operations take place because of the high value of the land, or the desire to reclaim the area by removing random housing, or to undermine the potentials of political resistance.

The demolition of slums represents a vicious circle, as it does not solve the housing problem, but in fact leaves people homeless without providing alternatives.

\subsubsection{Resettlement}

Resettlement depends on the provision of alternative housing for slum dwellers in the city by the government.

The government is unable to resettle all the inhabitants of degraded areas as:

- Building large numbers of new housing units exceeds the financial and managerial capacity of governments;

- The high rate of urbanization and migration from rural to urban areas exceeds what the government is capable of, especially in developing countries.

\subsubsection{Promoting}

Improving poor areas includes the gradual improvement of the physical environment and social and economic development without population transfer.

Characterized upgrades result in low cost of other alternatives; it is also more humane and improves the housing stock, rather than removing it.

\subsubsection{Planning Sites and Services}

The strategy of planning sites and services represents a turning point in the role of the state to produce housing units. This strategy aims to share the responsibility of providing housing units at affordable prices for low-income people, between the government and the targeted communities. The government has the responsibility to prepare the land plots and to provide the infrastructure required for building a house. While the project is to provide lease loans, technical support and building materials. Some projects may include a gradual cost-recovery plan; each project is to be supported by the state.

Some projects provide land and facilities.

\subsection{Become Clearer after Studying the Previous} Alternatives for Dealing with Slums

Upgrading keeps people together in the same place in which they have lived for a long time. This helps to unify communities and promote social stability, and supports existing mutual support mechanisms; Upgrading encourages participation: upgrading motivates people to participate first in the planning and implementation of the upgrading project, and then in the various social and economic activities, which are managed collectively within the community.

Enhancing the investment: Housing for the stability of property rights are gained through collective bargaining to secure land tenure (Fig. 6).

Upgrading improves the quality of life for residents

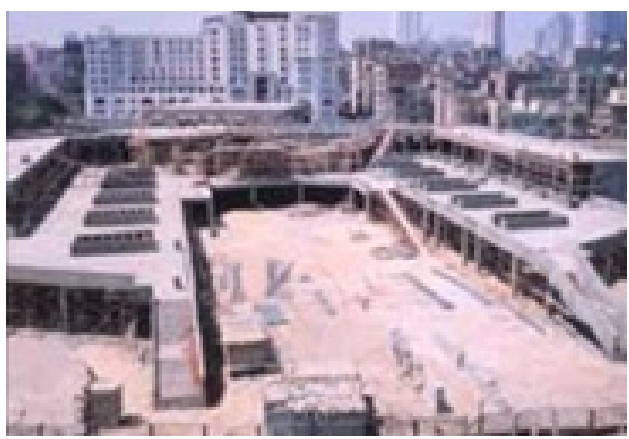

(a) Reconstructing slums areas with new legal and planned buildings.

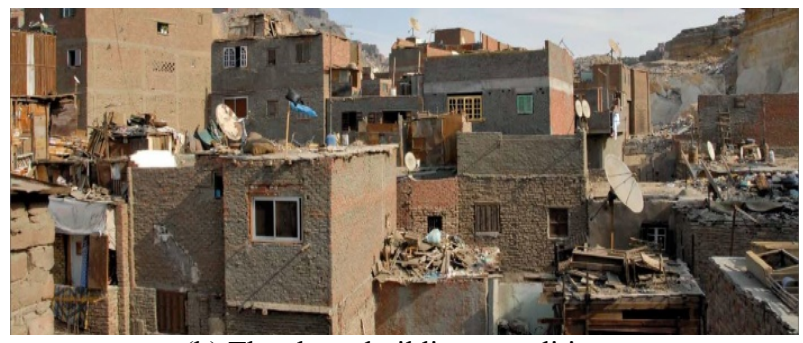

(b) The slums buildings conditions

Fig. 6 Al-Mawardy district. 
by improving housing, health services and the development of regional economy, and provides people with security against the threat of expulsion.

Upgrading raises the value of homes and land assets, through home improvement and land tenure security. Thus, assets can be used for income-generating activities.

Upgrading improves the urban environment through the empowerment of the population by re-zoning, planning to supply utilities and services, taking care to consider any changes in the boundaries of individual land ownership (Fig. 7).

Upgrading improves income by enabling people to use their homes in income-generating activities.

\section{International Experiences in Dealing with Slums}

The following part are some successful models that deal with the problem of slums in various countries.

\subsection{Brazilian Experiences in the Integration of the Slum Community (Upgrade)}

The government in Brazil held panel discussions with residents through 200 workshops over several years to listen to their vision of possible solutions. Then the government began an effective plan to eliminate slums not by simply building healthy housing, but also by creating green spaces, music halls and open activities [4] (Figs. 8-10).

Through dialogues and meetings with many government bodies, the power of gangs in these areas was managed or dismantled. In addition, benefits were provided to the population to build some roads and upgrade homes and services, as well as to set up housing rehabilitation centers and education, and help people to get jobs.

These programs also include financial incentives and better social care for people who collaborate with the government, as well as classes in those neighborhoods, football stadiums and entertainment venues in which the focus was on youth and children, as well as the elderly. Removing slums was not a part of a public plan in Brazil, because it is an expensive and difficult

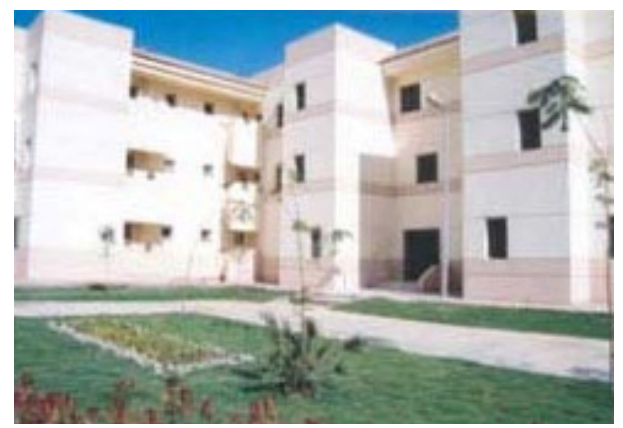

(a) Building in new urban environment in new city

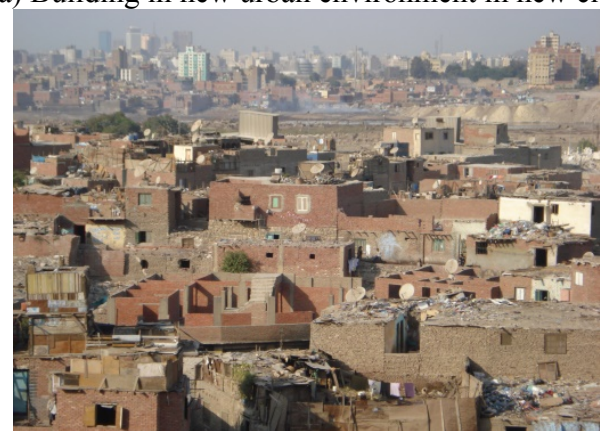

(b) The slums conditions in Egypt

Fig. 7 Zeinhom district before and after development (upgrade policy).

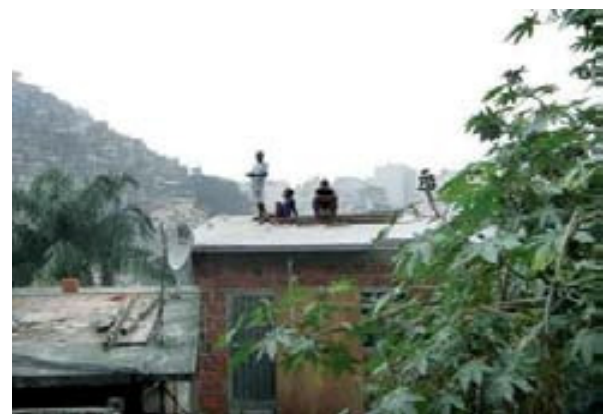

Fig. 8 One of the slums districts in Brazil (development upgrade policy) [4].

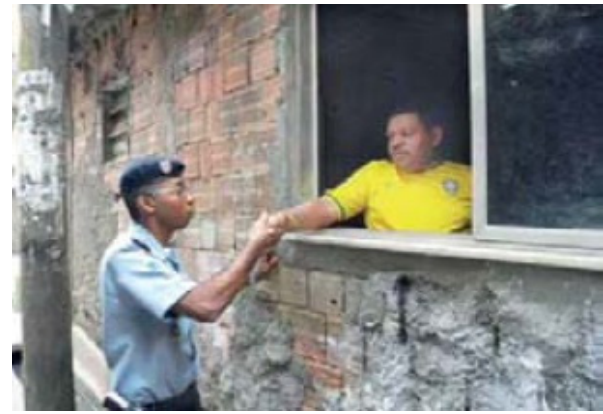

Fig. 9 The good relationship between police officers and people living slums in Brazil, which decreases the crime ratio [4]. 


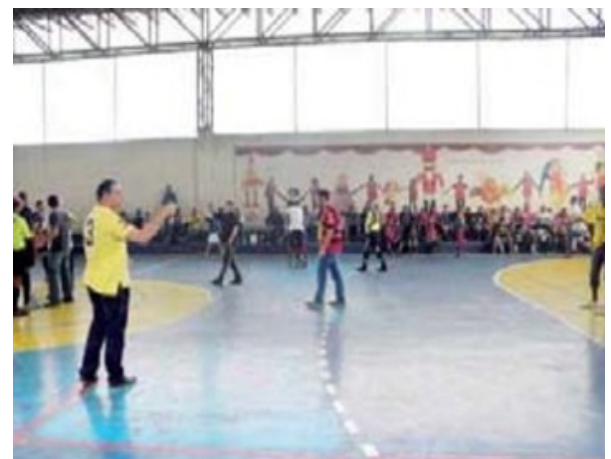

Fig. 10 A sports court established in poor districts (in development upgrade policy) [4].

policy, but at least the plan succeeded and was applied in about 17 areas on the slopes of The Mountains of Rio de Janeiro, in collaboration with the residents themselves.

\subsection{Experiences in Hop, Bath, York and Glasgow, the UK (Resettlement)}

Resettlement policies in Hop, Bath, York and Glasgow in the UK (United Kingdom) were designed to rehabilitate and revitalize historic areas, which have moved out randomly. Preserving the traditional character, reusing antique buildings and encouraging factors such as tourism turned these areas to crucial zones and valuable places culturally, socially and economically. This policy provides the implementation of programs to improve the development and revival of the old areas and slums, and set policies through two solutions:

- improving all housing and service conditions;

- adopting municipal housing programs after the removal of slums - whether partially or entirely —after the transfer of residents.

\subsection{The Experience in Mumbai, India (Resettlement)}

Mumbai, the capital of the state of Maharashtra-India, the most vibrant commercial center, has a population exceeding 12 million people. More than half of the city's population lives in slums [5].

Governmental actions are as follows:

- In the 1950s-1960s, the government demolished slums and cleared any land on which the poor encroached;

- In the $1970 \mathrm{~s}$, for a variety of reasons relating to equity and practical considerations, slums began to be viewed as "housing solutions";

- In the $1980 \mathrm{~s}$, there was a change of thought as World Bank programs for the upgrading of slums and of low-income groping shelters were implemented [6];

- In the 1990s, a new slum redevelopment scheme was formulated;

- In the $21 \mathrm{st}$ century, an offer was made to reallocate people to a 225 square-foot apartment for each family and to give 20,000 RS per family.

Taxis lowered their fares by $20 \%$ to encourage people to invest in the redevelopment era.

\subsection{The Housing Crisis of Refugees and Displaced People in Azerbaijan}

At present, there are nearly one million refugees and IDP (internally displaced people) in Azerbaijan, which makes up $12 \%$ of the total population. Despite the fact that those 14 years have passed since the beginning of the Armenia-Azerbaijan conflict, over 1,722 refugee households have not settled permanently. Within the IDP population, there is still a sizeable group living in unsatisfactory and precarious conditions. After 10 years, over 55,000 of them still live in tent camps, nearly 32,000 live in prefabricated temporary houses, 57,000 live on farms and in dig-outs, and about 8,000 live in railway cars and the rest in hostels, public buildings, and unfinished construction buildings with no utilities. Long-term solutions are being envisaged through resettlement (as the original homes in Walicki demonstrate), or restitution and compensation schemes. The government of Azerbaijan has allocated some 60,000 ha of state and municipal land to IDPs and created 760 farms providing livelihoods for about 47,000 IDPs so far (Fig. 11).

\subsection{Provision of Social Infrastructure and Community Facilities in Kamza}

The Municipality of Kamza is one of Tirana's 
informal housing settlements with over $90 \%$ of all dwellings being constructed illegally. The primarily think of the settlement is agricultural land in the early 1990 s, but grow substantially to around 60,000 residents today. Residents have emigrated from the northeastern regions of Albania, with the hope of a better life and opportunities. Children (aged $0-15$ years) account for $40 \%$ of the population, adults have low-level education, high unemployment rates (around $50 \%$ ) and half of all households live below the poverty line (Municipality of Kamza, 2002) (Fig. 12).

The plan below shows the proposed land use and social infrastructure of Kamza where the planning process attempts to identify the location of much-needed public open space, schools and medical facilities. The average density of the area is 22 people per hectare, while the average home is $119 \mathrm{~m}^{2}$, twice the average for Tirana. Housing is initially built in stack form and then upgraded as remittances received

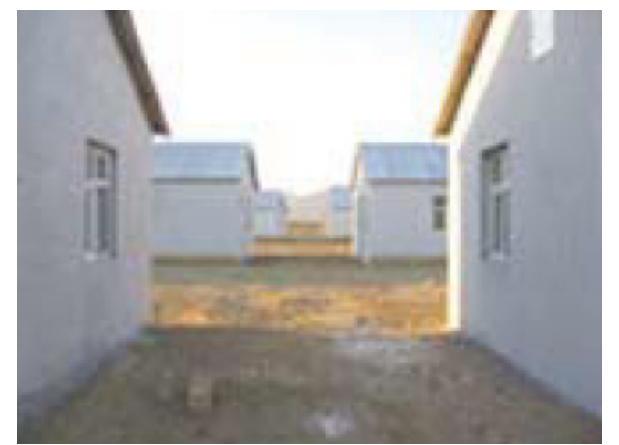

Fig. 11 The designed districts for emigrants in Azerbaijan [7].

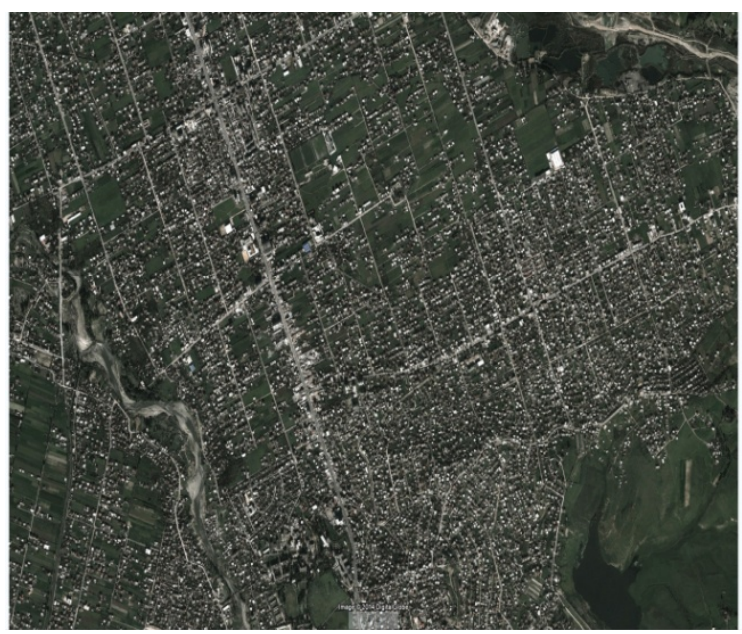

Fig. 12 Kamza map. and resources found. While planning efforts and the work of NGOs (non-governmental organizations) such as Co-PLAN have boosted the confidence of residents and led to US\$110 million investments, its limited revenue of the local government in Kamza is involved in complex negotiations with the squatters to gain land for social infrastructure [7].

\subsection{Special Rehousing Programs in Lisbon, Portugal}

More than 130,000 families living in shantytowns in the metropolitan areas of Lisbon and Porto have (or will have) access to adequate housing, in some cases after living in shantytowns through generations. The special rehousing program-PER (Program Especial de Realojamento) - launched in 1993 was expected to eliminate shantytowns (slums) in the 27 participating municipalities by 2001. It was a practical implementation of the ideological slogan that emerged from the enthusiasm of the 1974 Revolution: "Houses, Yes. Barracks, No.”

Estates in Lisbon and Porto metropolitan areas have become the new home of more than 94,000 families. PER is still $30 \%$ short of its original target and its timeframe has been extended. The program operates with the extensive support of the central government covering $40 \%$ of the costs with another $40 \%$ covered by municipalities through soft loans for a total of $€ 1,280$ million by the end of 2006 . The remaining $20 \%$ are municipal in-kind contribution through land and infrastructure. Housing is built by private firms under contractual arrangement at fixed prices regulated by the state [8].

In Lisbon, PER has added close to $30 \%$ of the social housing stock $(8,700$ apartments). This recent growth was due to reallocation initiatives (by PER and its predecessor PIMP); it has also raised new challenges for the management of those new urban territories. The need for an integrated management of public housing stock (both new and old) resulted in different sets of urban, social and economic problems, which come as calls for a gradual involvement of the 
different public and private sectors within a system of organized partnership. The PER experience has seen the emergence of some well-accomplished initiatives in this domain, and one may expect improvement towards a more efficient management of the new housing estates in response to the changing needs of the residents (Fig. 13).

From the above, we can conclude that dealing with the problem of slums and shantytowns requires processing, upgrading and improving. Below, the problem of Ezbet Khair-Allah will be discussed along with some solutions that could have changed and can change the crisis.

\section{Aspects of Slums}

There are some similarities conditions in all of slums urban tissue as following:

- having random streets, bad and irregular road networks with jagged streets, some of which are hard to reach;

- mixing of dirty and polluted tools especially in workshops and trades;

- deterioration of buildings; some of them are incomplete, which gives an impression that they are in bad condition;

- crowding in the same room;

- low and few services and utilities;

- lack of general culture and knowledge, low social behavior, and the spread of ignorance;

- presence of a lot of crimes;

- unemployment;

- lack of privacy.

\section{Examples from Egypt}

\subsection{Ezbet Khair-Allah}

One of the strategies recently developed by Cairo governorate is raising the level of residential areas that integrate slums within them. That is why, the area of Ezbet Khair-Allah, in Old Cairo, was selected in the development program due to its large size and lack of utilities and services (Fig. 14).
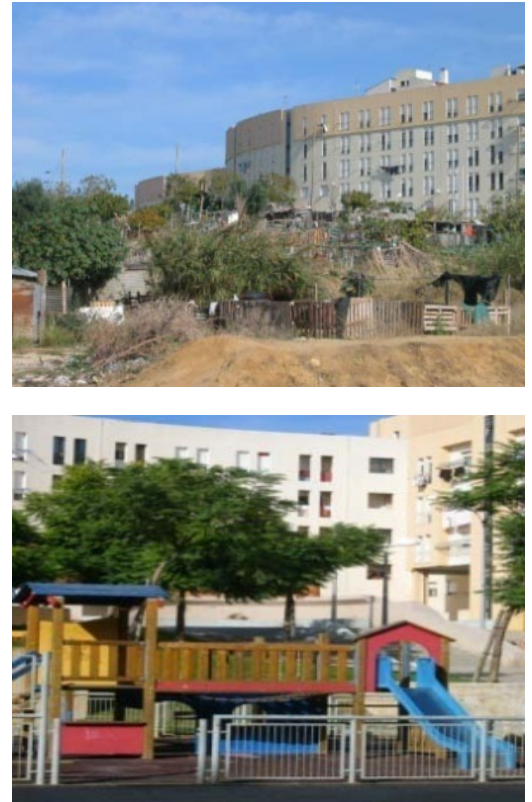

Fig. 13 Re-housing program in Lisbon [8].
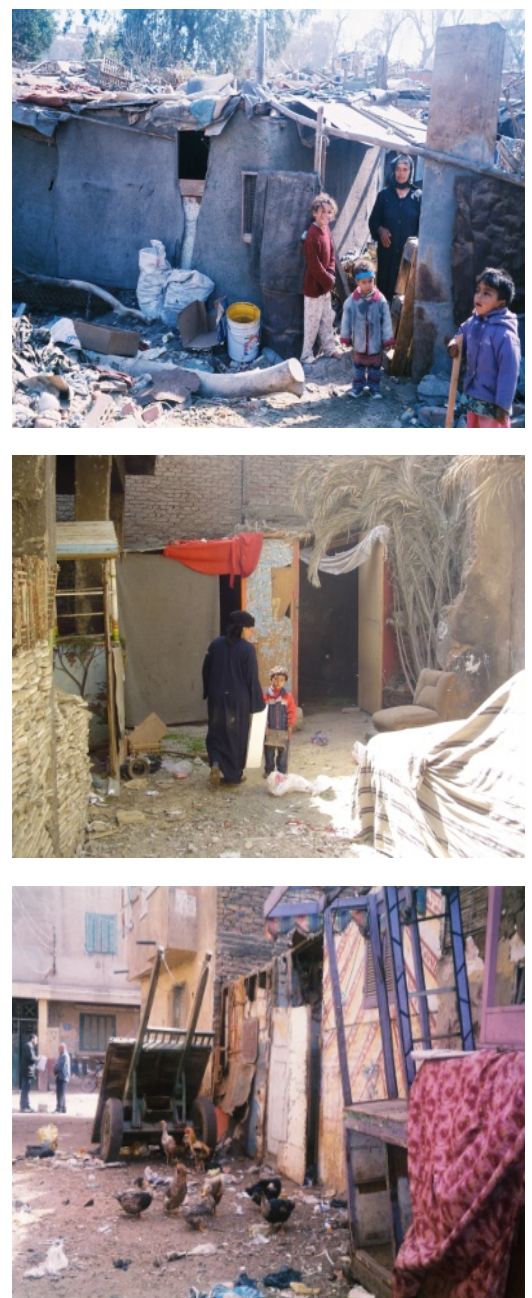

Fig. 14 Scenes from inside slums to show people's living conditions. 


\subsubsection{Site}

Ezbet Khair-Allah is situated on a high rocky ridge. The most important roads leading to the area are:

- Salah Salem from the north;

- The ring road penetrates Ezbet Khair-Allah, dividing it into Ezbet Khair-Allah and Antar Stables;

- Al-Khayala road from the east;

- Corniche El-Nile from the west.

\subsubsection{Borders of Ezbet Khair-Allah}

From the north, the area is surrounded by Ain El-Seera hills. From the south, there is Al-Mahgar Street, then Dar El-Salam and El-Basateen neighborhoods. From the east, there is Al-Imamayn Street then Al-Basateen graves and finally from the western side, there is the residential area of Zahraa Old Cairo.

\subsubsection{Area of Ezbet Khair-Allah}

Ezbet Khair-Allah covers a total area of approximately 480 Fadden's.

\subsubsection{Ownership}

Ezbet Khair-Allah is owned by the Egyptian government and is subject to the Law on the Protection of Monuments No. 117 of 1983. Under the decision No. 158 of 1981, the area may not be developed without going back to the Egypt Tourism Authority as it includes part of Cairo's historical heritage. In addition, the area is situated within the privileges of the Maadi Company for Development and Reconstruction pursuant to the Presidential Decree No. 1420 of 1974 and Presidential Decree No. 1187 of 1972 to establish a residential city on the land (The New Fustat City). However, area residents have acquired the land by force.

\subsubsection{Significant Monuments in the Area}

The area is subject to the Law on the Protection of Monuments No. 117 of 1983 as it includes various artifacts dating to several eras, and they are:

- The Antar Stables Fortress;

- The Seven Domes (The Seven Daughters);

- Al-Khadra Al-Shareefa Prayer Area;

- The digging area of the French Mission;

- The wind mills area;

- Abou-Ali area.
4.1.6 The Historical Development of the Residents in the Area

Due to the presence of a residential area in Dar El-Salam and Al-Basateen, urbanization moved towards the northern section of Ezbet Khair-Allah.

The presence of an industrial area in Al-Basateen and Al-Zahraa, as well as an area for factories and Ithr El-Nabi market place, all this has led workers coming from the countryside to build random residential units in the area so they can live near their workplaces.

In addition, the fact that the Batn el Baqara random area is not big enough for its residents has led to additional random building in the southern area of Ezbet Khair-Allah (Fig. 15).

The presence of areas full of monuments in Ezbet Khair-Allah represented in the Antar Stables, Al-Khadra
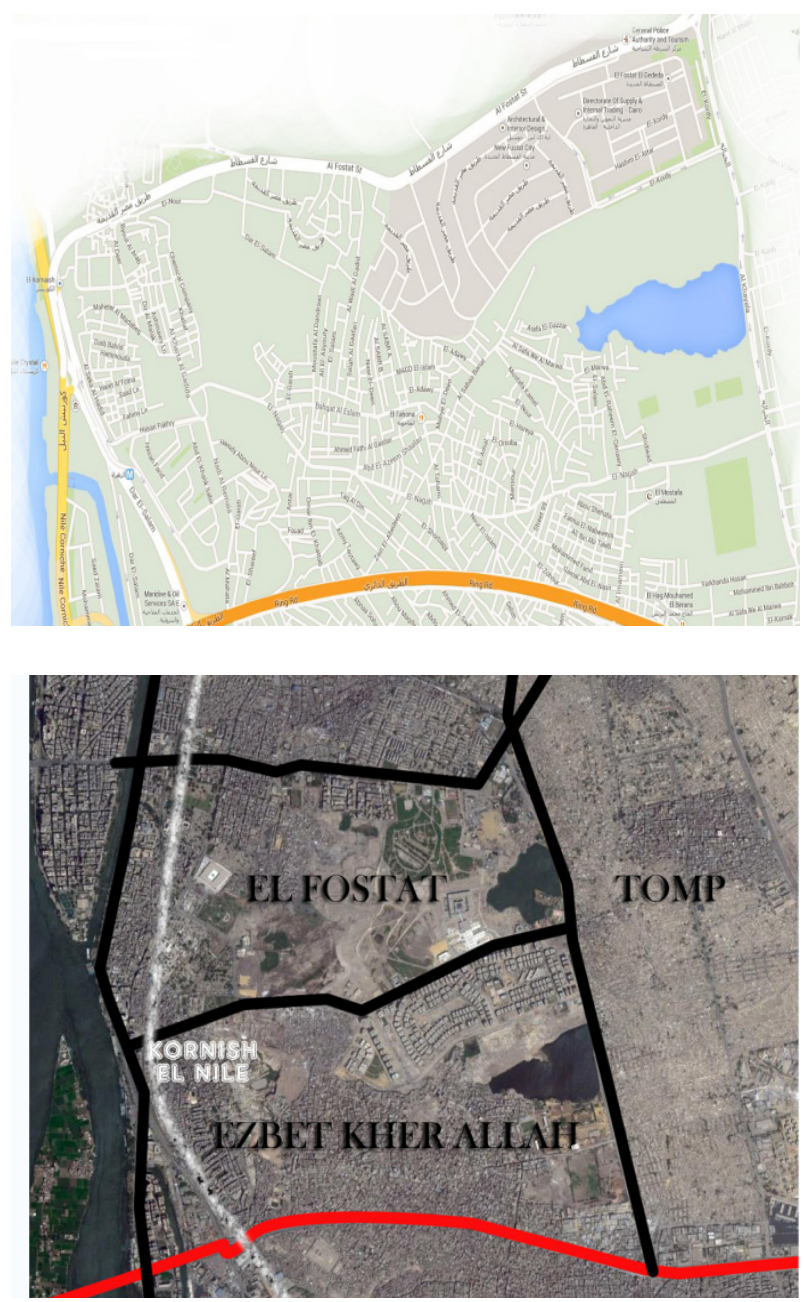

Fig. 15 Location of Ezbet Khair-Allah. 
Al-Shareefa prayer area and the windmills has led to the spread of residential random areas alongside these monuments.

\subsubsection{Problems}

\subsubsection{Introduction}

Like many random areas and slums, Ezbet Khair-Allah suffers from many problems, such as the spread of illiteracy, unemployment, disease, crime, poor construction conditions, poor traffic and means of transport, poor services and utilities, increased construction, etc. (Figs. 16 and 17).

\subsubsection{The Examples}

The lack of services and utilities leads to the death of either many children as pedestrian crossings are submerged in water or there are not any.

Having a pedestrian crossing beneath the Ring Road Bridge in Ezbet Khair-Allah submerged with drinking water mixed with sewage (waste water) has resulted in many pedestrian accidents and the death of many children. People in the area reported the explosion of a

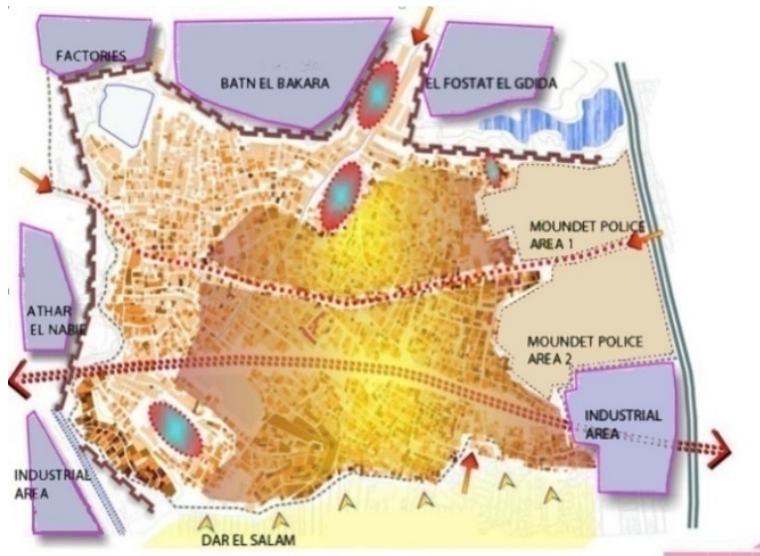

Fig. 16 Historical development of the residential grows.

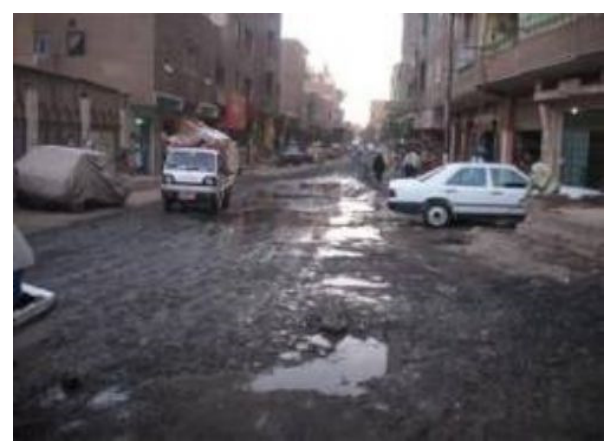

Fig. 17 Bad road condition. drinking water pipe and a sewage pipe (more than 15 days ago). They said that they notified Police authorities, the drinking and waste water company as well as the Dar El-Salam neighborhood authorities but no steps have been taken to solve the issue.

Moreover, the disruption of pedestrian traffic in the tunnel, especially for children, causes daily traffic and pedestrian accidents on the Ring Road. One of the people living in the area said that all bread-bakeries, fruit-and-vegetable markets and primary and preparatory schools lie on the other side of the road; that is why people have to cross the highway with their children, which results in many accidents.

Spread of Thugs and Absence of Security: Following the events of the January Revolution in Ezbet Khair-Allah and neighboring areas in Al-Basateen neighborhood, people suffered from thugs selling of drugs and terrorizing the people with knives and other weapons. Moreover, police forces have not taken any steps to prevent these thugs and it seems that they prefer to be bystanders to these ongoing criminal acts.

A housewife in the area says: "We live in fear and terror. I have five daughters and I worry about them because there are thugs in the area, especially since there have been reports that they have attacked girls in the area before." She says that the thugs begin working at around 8 p.m.. They follow girls, terrorize them then lure them to dark and empty areas and attack them. "We have no one to guard us and there is no police protection", she says, adding that people have filed many complaints to those responsible to create a police station in the area but their complaints fell on deaf ears. She adds that they have demanded that the governorate provide alternative homes and accommodation because the units they live in are unfit for humans as they are infested with locusts, insects and mice, which have become regular guests of the household. Still, their demands have been unmet.

Military Police Rescue Police Officer from Ezbet Khair-Allah Citizens. Military police led by Brigadier 
Shebl Abdel-Gawad succeeded in rescuing police officer Alaa El-Sayed Abdel-Halim. Part of the Dar El-Salam Police Department, after citizens in Ezbet Khair-Allah held him hostage following the accidental death of a resident due to gunfire from Amr Gamil another police officer, during the latter is pursuit of three brothers.

Following the incident, more than two-thousand residents in Ezbet Khair-Allah crowded and tried to kill the police officer. However, Military Police personnel succeeded in rescuing the police officer and in catching the other runaway officer.

Bad Condition of Buildings and Overall Urban Status: On July 13, 2010, a house collapsed in Ezbet Khair-Allah on Al-Mahgar Street. This incident is similar to the collapse of the Doweiqa Rock, which resulted in the death of more than 200 people as well as the injuring of several others. The vice-governor and seven others were sent to prison at the time.

Lake contaminated with sulphurous materials is also one of the examples.

\subsubsection{Redevelopment Limitations}

Some limitations need to be taken into consideration when attempting to redevelop Ezbet Khair-Allah or find solutions for the area. These include important historical monuments, main roads linking the area to the capital and other limitations that must be respected.

4.1.9 The Limitations That Must Be Taken into Consideration When Searching for a Solution for Ezbet Khair-Allah

The main roads that serve the area are:

- Salah Salem from the north;

- The ring road penetrates Ezbet Khair-Allah, dividing it into Ezbet Khair-Allah and Antar Stables;

- Al-Khayala road from the east;

- Corniche El-Nile from the west;

- Ain El-Seera Hills area;

- The Seven Domes (The Seven Daughters);

- Al-Khadra Al-Shareefa Prayer Area;

- The windmills.

More than two million people have built their homes on state-owned land that is affiliated to the Maadi Company for Development and Reconstruction in Ezbet Khair-Allah, Dar El-Salam, Cairo governorate, since 1960. Over the years, they have paid the specified rent value, on a regular basis, in return for keeping the land, until the received the Decision No. 1342 of 1993, which gave them the right to own these lands. The decision has not been implemented, although 19 years have passed since its issuance.

\subsubsection{Charities and Their Roles in Slums}

Charities and NGOs are those that attempt to find solutions to serve slums and their inhabitants, whether through educational, social or health-based services, or any other services. These NGOs depend on donations by the public and by businessmen.

There are many examples of NGO activities in Ezbet Khair-Allah, such as:

- Dar El-Salam NGO Coalition;

- Nahdet KhairMasr Association;

- Shabab Dar El-Salam Association;

- Emaar Ezbet Khair-Allah Association;

- Twenty other similar associations.

4.1.11 Suggested Solutions and Other Solutions That Were Implemented in Ezbet Khair-Allah

These associations have taken several developmental decisions, including (Fig. 18):

- establishing an open playground and a primary school;

- fighting the garbage problem particularly in Al-Imamayn Street;

- forming developmental committees in the fields of: education, health, environment, economy, child-car, etc..

Other projects include:

- Performing a study on the physically disabled and providing wheelchairs, walkers and crutches;

- In December 2011, an article was published stating that the area required a public hospital, a post office and an ambulance station;

- Around 1,100 families from Ezbet Khair-Allah were transferred to new homes in the Sixth of October City, emptying an area of 50 Fadden's; 
- The Housing Ministry approved 100 million Egyptian Pounds to create private projects related to housing and utilities. In addition, they created alternative plans to suit Ezbet Khair-Allah.

Moreover, college students often examine developmental projects in slums and random areas in competitions, studies, or architectural engineers, who have indeed presented developmental projects that serve the people in random areas and contribute to finding solutions to the problems facing Ezbet Khair-Allah.

\subsubsection{Examples of Students' Projects}

\subsubsection{Funding Project}

Funding methods: Annual, semi-annual (every 6 months), one-pound per person per month funding, minor taxes on shops and factories; these are determined based on the decision-makers' decisions.

Population: 650,000 , ten pounds per person per year: $10 \times 650,000=6,500,000$ L.E. (six million and five-hundred thousand Egyptian pounds). In case of 20 L.E. per person: $20 \times 650,000=13$ million pounds. One pound per person per month: $12 \times 650,000=7,800,000$ L.E. (seven million and eight-hundred thousand pounds). Minor taxes of five pounds on commercial shops (60 L.E. per year): 2,315 shops $\times 60=138,900$ L.E. (one-hundred thirty-eight thousand nine-hundred pounds). Factories and workshops: $60 \times 516=30,960$ L.E. (thirty-thousand nine-hundred and sixty pounds). If the total amount of what can be gathered as a minimum equals $6,500,000+138,900+30,960=$ $6,638,900 \quad$ L.E. (six million six-hundred-and-thirty-eight thousand nine-hundred pounds). The average of what can be collected is: $7,800,000+138,900+30,960=7,969,860$ L.E. (seven million nine-hundred-and-ninety-six thousand eight-hundred-and-sixty pounds). The maximum that can be gathered based on Fig. 18 would be: 13,000,000 $+138,900+30,960=13,169,860$ (thirteen million one-hundred-and-sixty-nine thousand eight-hundred-and-sixty pounds).

4.1.12.2 Road-Pavement Project

The cost of paving one kilometer of road $=350-450$

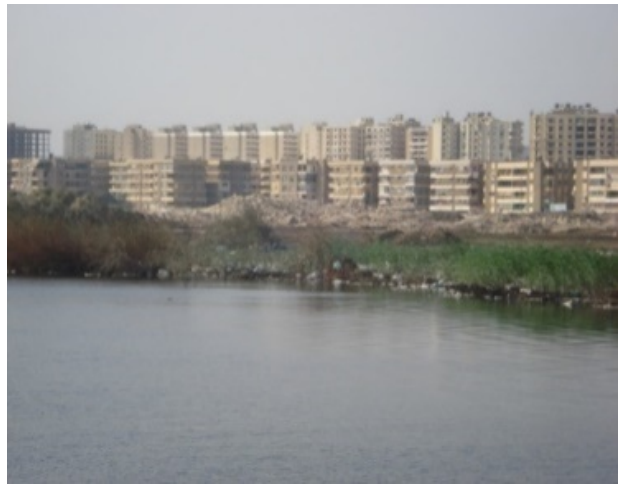

(a) The urban view

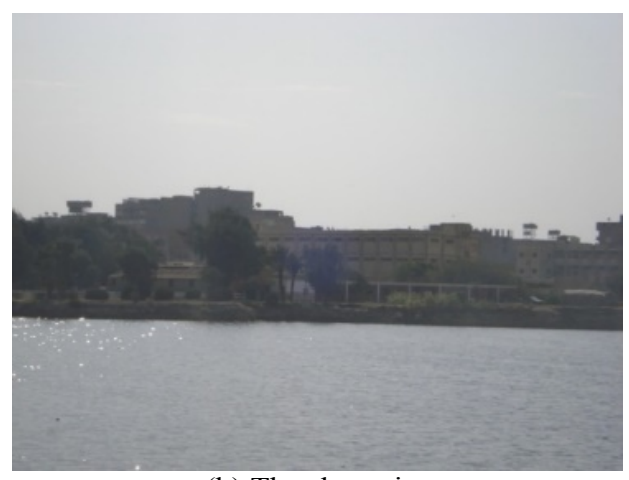

(b) The slum view

Fig. 18 Different view of the sulphurous mineral water.

thousand pounds at a 5-cm tar thickness. Total length of unpaved roads $=57,708 \mathrm{~m}$ (around $58 \mathrm{~km}$ ). Total area of unpaved and semi-paved areas $=204,556 \mathrm{~m}^{2}$. Thus, the cost of paving these roads would be = $400,000 \times 58=23,200,000$ L.E. (twenty-third million two-hundred thousand pounds). These projects are implemented on several stages. According to the previously mentioned simplified case studies, the road-pavement stage can be completed within two years, three years, or four years. Semi-paved roads can be taken at a later stage. Length of semi-paved roads $=$ $23,494.961354 \mathrm{~m}=$ around $23.345 \mathrm{~km}$. Cost of paving these roads $=400,000 \times 23.345=93,380,000$. Thus, this stage can be completed within a year or a year and a half (Figs. 19 and 20).

\subsection{Mansheyet Nasser Area}

Another example of random areas is Mansheyet Nasser, which lies at the heart of Cairo and on a main road, which is the Autostrad Road. This area suffers 


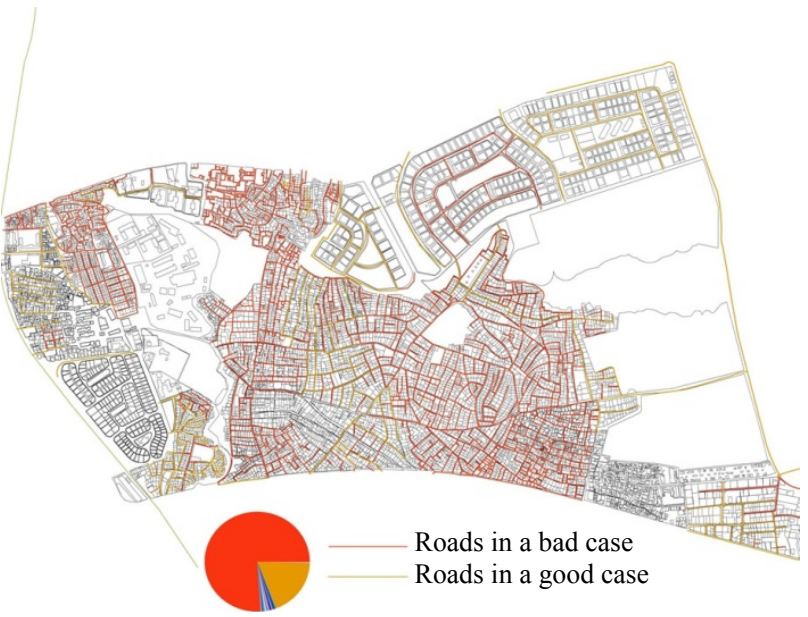

Fig. 19 The road condition.

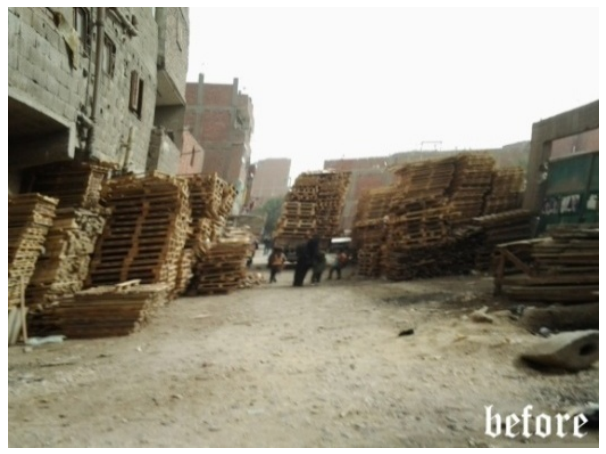

Fig. 20 The road before and after development. like other slums in Egypt.

4.2.1 Specialized NGOs in Mansheyet Nasser Area

Amar YaMasr Association is one of the NGOs that has a strong presence and that plays an active role in developing and improving random areas. The efforts seen in the area of Mansheyet Nasser include improving building facades, paving roads, and creating gates for main roads are great solutions; however, the problem with these solutions is that they are temporary.

Figs. 21-24 show one of the solutions that worked on improving and developing building facades in Mansheyet Nasser.

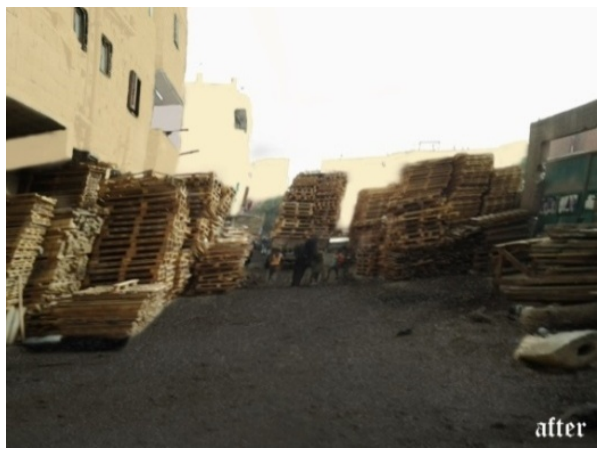

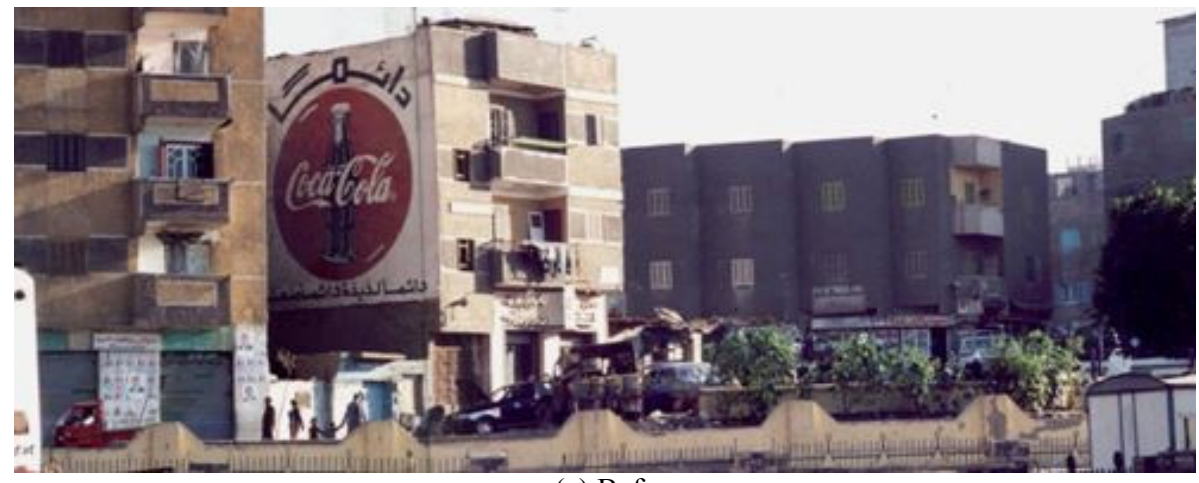

(a) Before

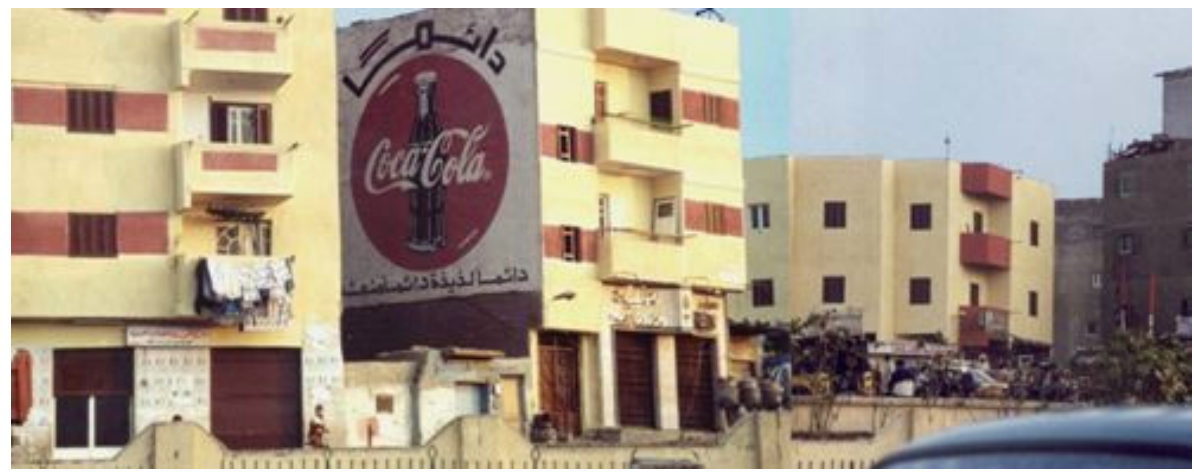

(b) After

Fig. 21 The houses before and after development. 

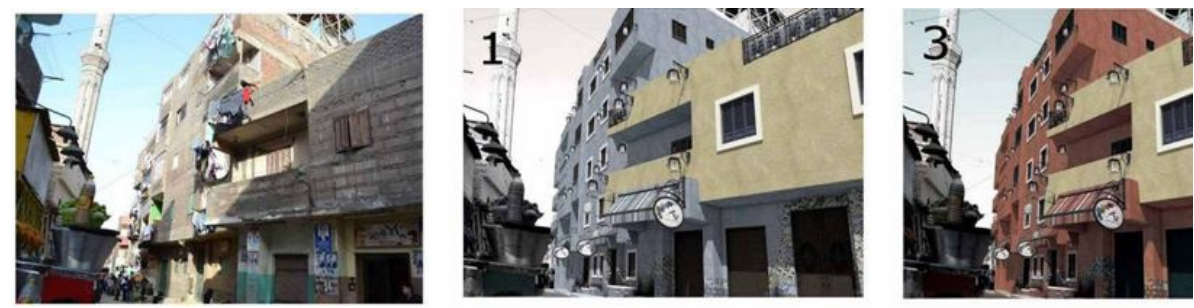

Earthly Colors
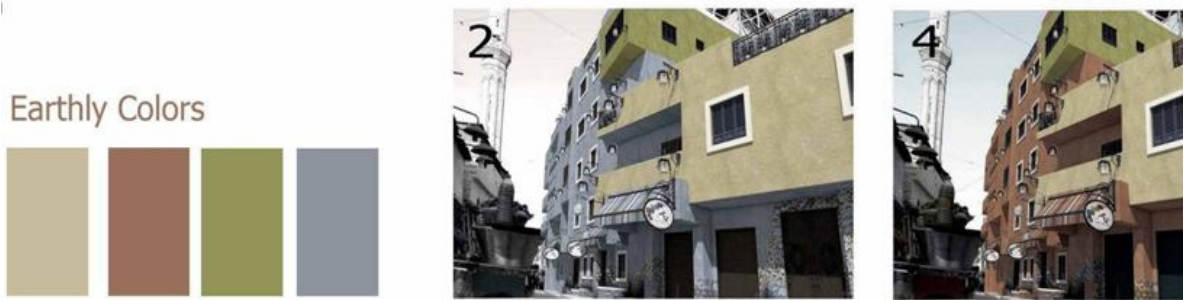

Fig. 22 The redevelopments of residential buildings facades, streets and lanes.
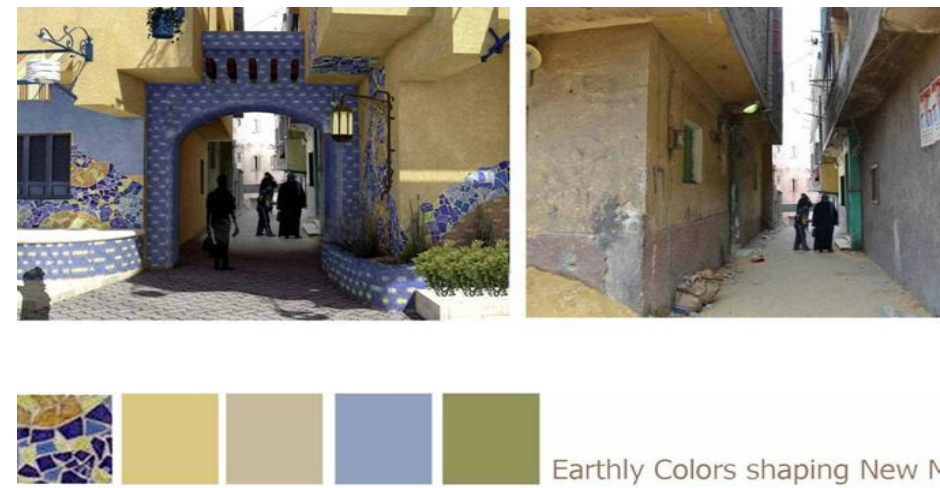

Earthly Colors shaping New Mansheya
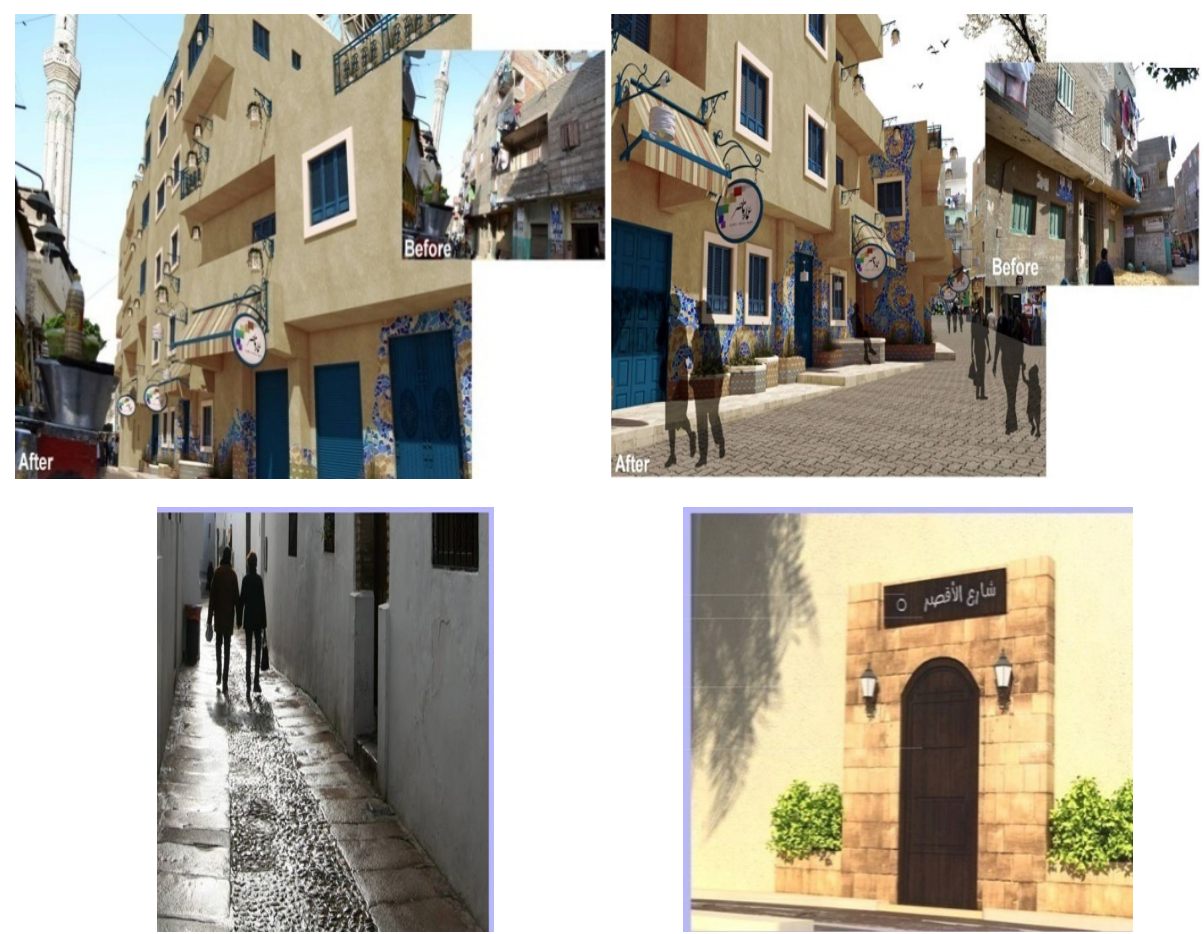

Fig. 23 The redevelopment of street entrances and its floors. 


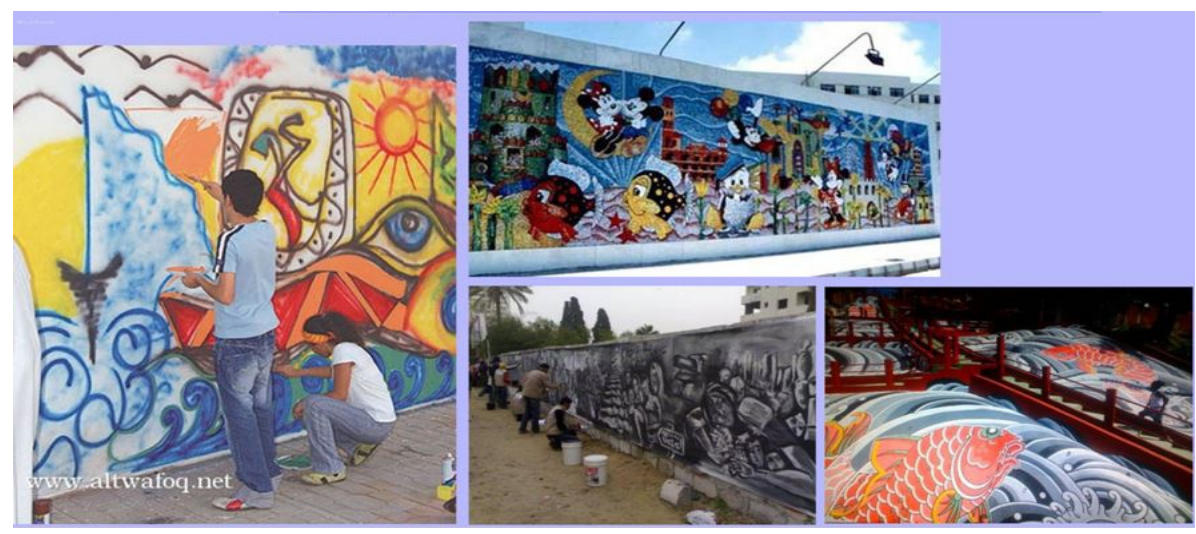

Fig. 24 The colors and paintings covering walls to give it another new spirit.

\subsubsection{Ezbet El-Haggana}

Region under research, location of the area: It is 2000 acres in northeast Cairo, surrounded by major roads, adjacent to formal settlements and military barracks (Figs. 25 and 26).

Population size: 32,000 people according to the 1996 census, 39,000 people according to the 2006 census, 400,000:1,000,000 by Davis (2006), 212,575 based on GIS (geographic information system ) analysis of the counted houses extracted from satellite images $(8,503$ buildings $\times 5$ households $\times 5$ people) (Fig. 27).

Sample of field survey: This is sample made by public authorities when searching for people with urgent need for donations. Women are the breadwinners of nearly $90 \%$ of families as the men are either sick or have passed away. Men hold different tasks such as carrying sand or furniture (most of them do not have constant income). The family average rate of income for (seven people) is 300 L.E. to 400 L.E., which is approximately US\$55 to US\$73 per month. Most of the people are uneducated. Most of the families lease their property and the leasing rate is 100 L.E.-150 L.E., which is equivalent to US\$19-US\$27 per month. Most of the houses are temporary ones. Some of them are without a ceiling and some rooms are without doors. Severe diseases are shown in Fig. 28.

Proposed solutions to deal with the area:

- Owing to the considerable population density in the area, two levels of operation become clear. The first is to work on improving the region; the second is to resettle the population (Fig. 29);
- Upgrading the region: The region is divided into several stages randomly. First phase of population was

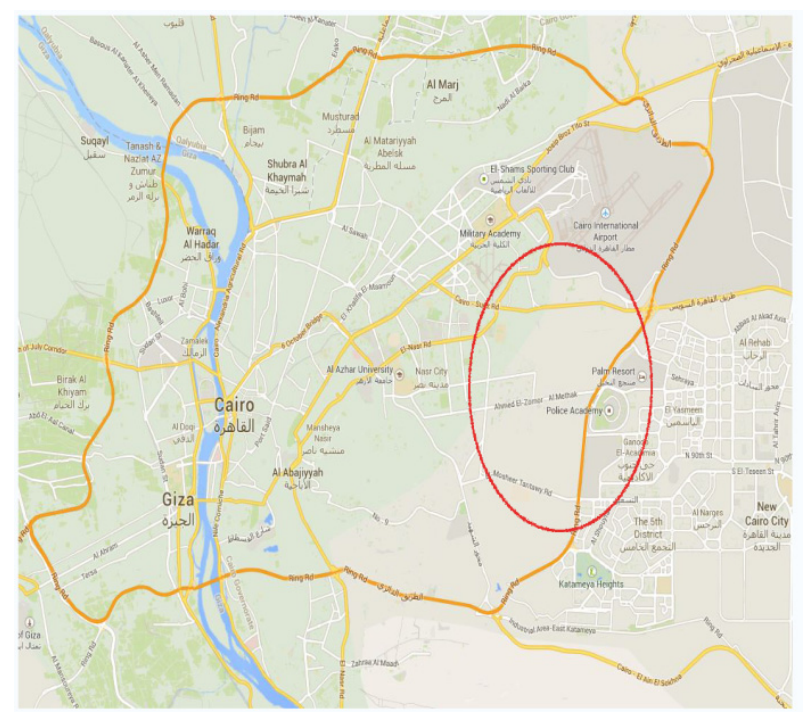

Fig. 25 The area of Ezbet El-Haggana.

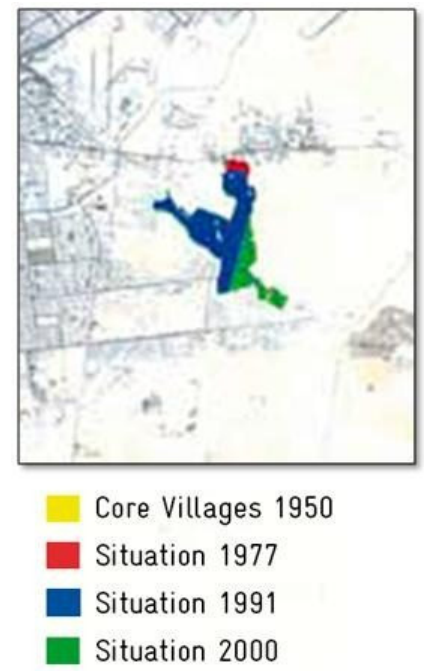

Fig. 26 The history of development of Ezbat-El Hannah [3]. 


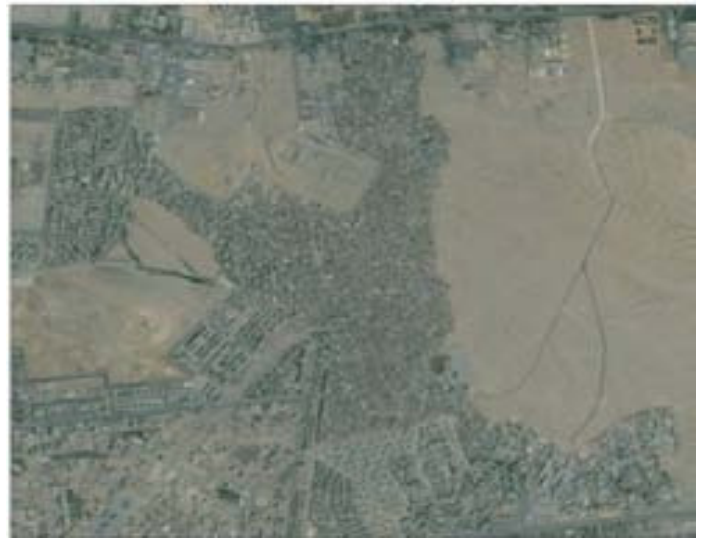

Fig. 27 A satellite picture for Ezbet El-Haggana.

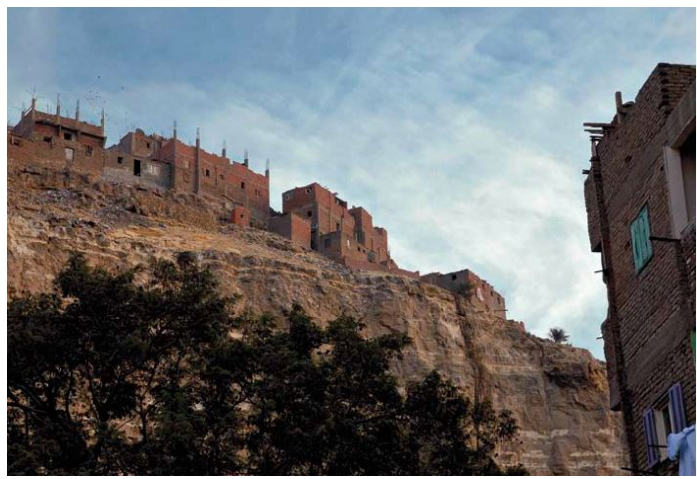

(a) Houses in haganna

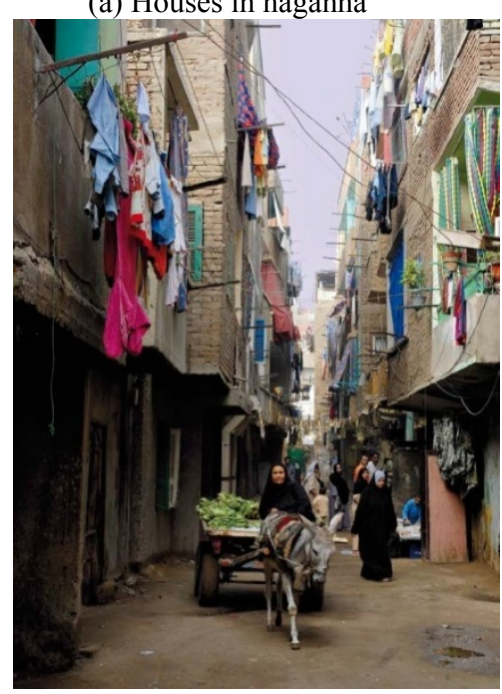

(b) Houses in community

Fig. 28 People living in severe conditions.

transferred to temporary shelter areas (to be under the control of the armed forces and the police); re-planning and construction phase; developing programs for training and rehabilitation of the population with the participation of civil society organizations. Repeating the same steps with the rest of the stages, the area should be divided into regions to simplify the construction works required; this may also be due to financial obligations (Fig. 30).

Architectural solution: It is to add a main central area for open spaces, services and commercial places. The reuse of the main axis leads to the circle in designing a commercial plaza. Patterns and grids from the urban surroundings are to be selected and redistributed, as the main parameter to compare between solutions is the density of population. During the upgrading process, the population should be transferred to places where they can set up temporary camps until the completion of the construction. Construction of housing, low-cost roads reduce the financial cost with high quality and speed in construction.

The resettlement stage: Owing to the heavy population density, partial resettlement of the population is suggested on several stages (Figs. 31 and 32).

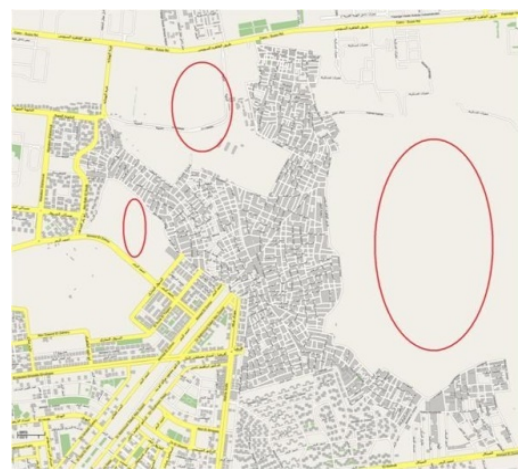

Fig. 29 The proposed places for temporary camps.

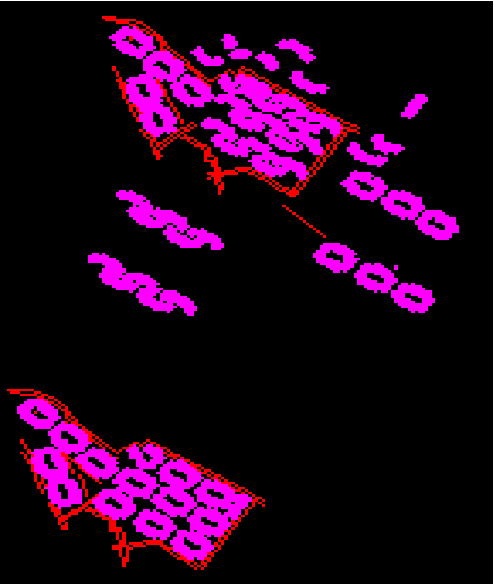

Fig. 30 The proposed urban patterns are formed from neighboring pattern forms. 


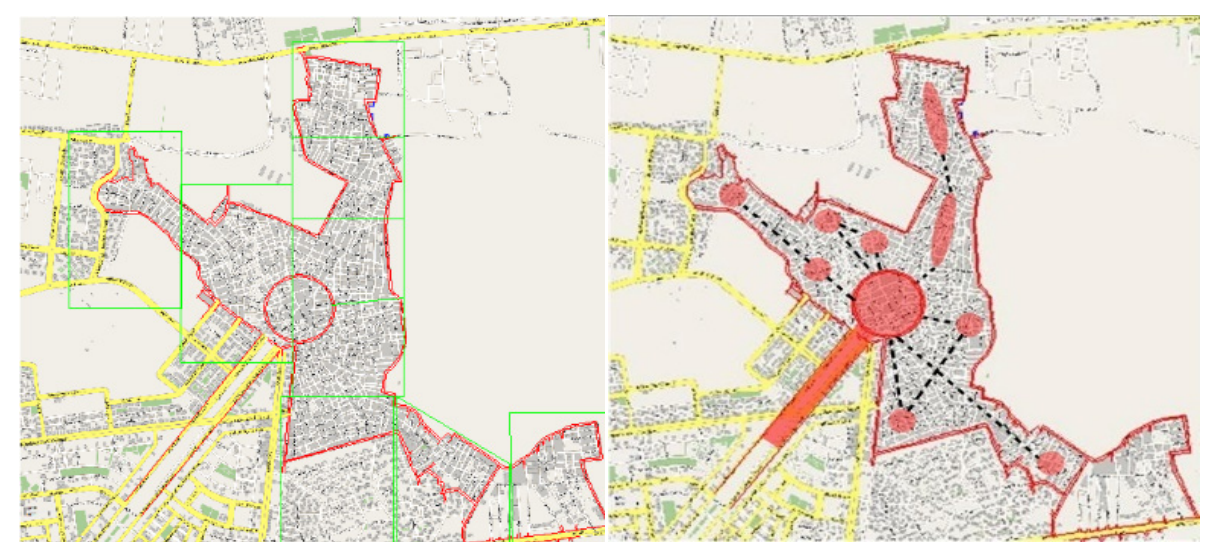

Fig. 31 A proposed location for a new city center and the area divided into zones.

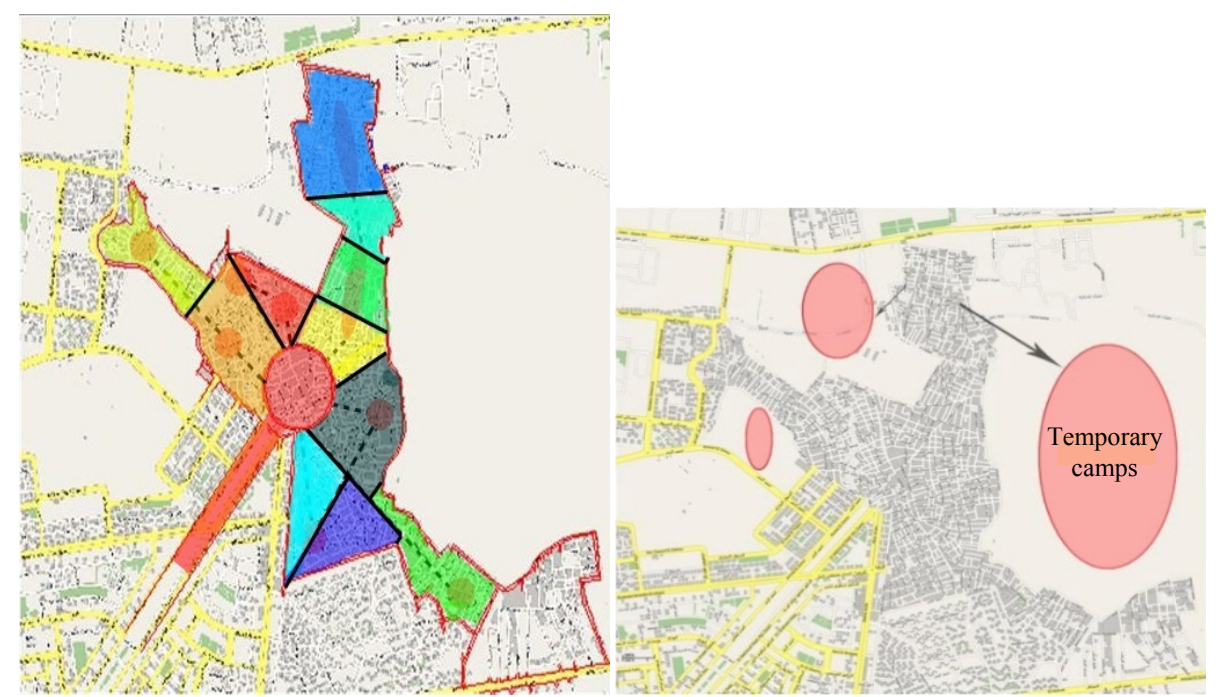

Fig. 32 The proposed locations along the development corridor.

Approaches: destroy and rebuild (temporary camp): Although it is difficult, it is sometimes required. Partial redevelopment: (partial-temporary) It is a solution though most of the problem remains. Investment aspect: Making a ring of public and private investment projects around the area.

Phases: The area should be divided into regions to simplify the construction works required. This may also be done due to financial obligations.

\subsection{The First Development Corridor Project}

The Development Corridor project by Dr. Farouk El-Baz aims to expand the green and unused areas in the Arab Republic of Egypt. The project mainly depends on lands formed by Nile sediments in the Western Desert, which is land that is fit for creating agricultural communities. In addition, the area will host a wide road consisting of eight lanes to and eight lanes back that are parallel to the railroad going to and back. The project also links the city of Al-Alamein in the north with the city of Aswan in the south (Fig. 33) [9].

The development corridor will be situated at a distance ranging from $20 \mathrm{~km}$ to $50 \mathrm{~km}$ west of the River Nile and will be linked to governorates by way of horizontal roads.

The project depends on water coming from eight areas, which are: west Aswan, west KomOmbo, west Esna, west Qena, west Assiut, west Matay, west Fayyoum and west Delta.

These areas contain underground water and already have agriculture. As long as the Nile exists, the underground water continues to be renewed. In addition, 


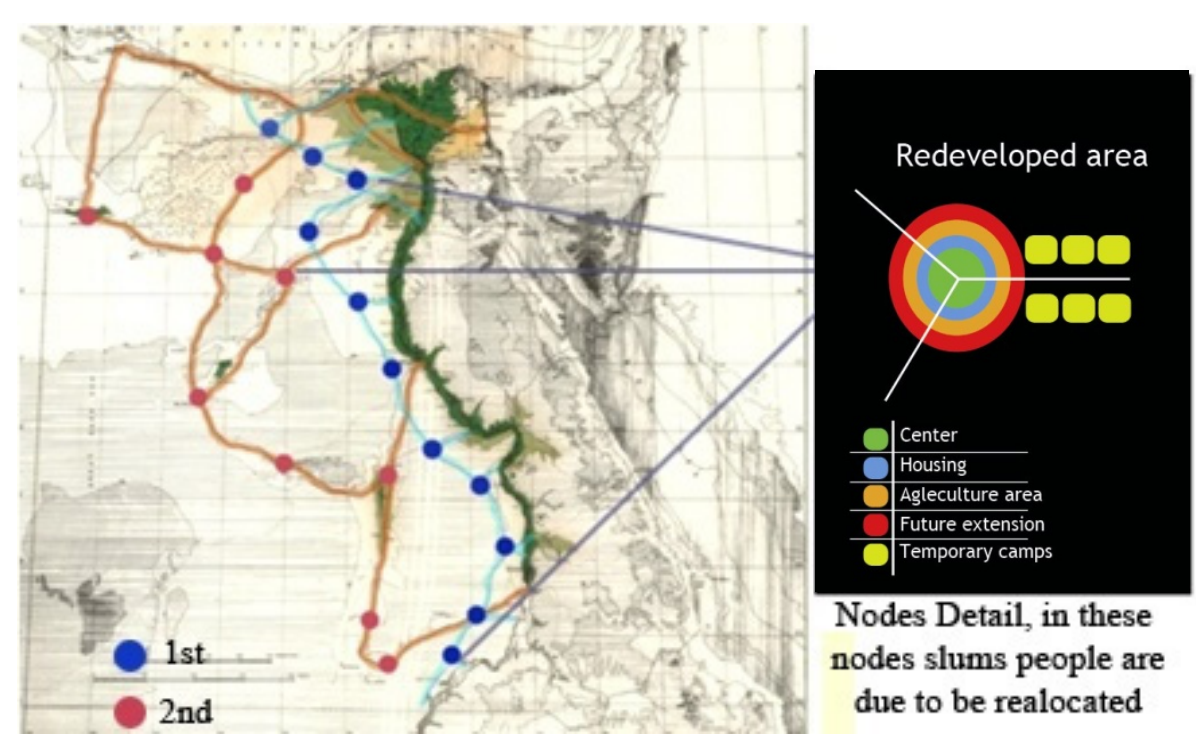

Fig. 33 One of the national solutions that were suggested by notable scientists includes the development corridor by Dr. Farouk El-Baz and the Second Nile Project by engineer Hany El-Adl.

there is a parallel river, which is the Nubian River.

\subsubsection{Financing the Project}

The financing of this project depends on Egyptian investors buying the land and on foreign investments which will only have the right to use the land.

4.3.2 Financing Suggestions in Relation to Using Garbage in Slums

Biogas is a combination of flammable gases produced by minute organisms when cattle wastes and biological wastes are left for fermentation in closed containers in the absence of air.

The best temperature for this process ranges between $32{ }^{\circ} \mathrm{C}$ and $37^{\circ} \mathrm{C}$. If the temperature drops below $15^{\circ} \mathrm{C}$, no gas will be produced.

Biogas is used in:

- Treating agricultural wastes and getting rid of them in a safe manner;

- Solving the problem of energy supply as it is better than burning wood;

- Methane gas is one of the best gases as it does not produce smoke;

- Methane gas is used to generate electricity;

- Allowing families to participate in social activities, self-improvement or making additional income;

- Solving the problem of sewage and improving daily agricultural and environmental hygiene;

- The remainder of the mixture to produce methane can be used as an organic fertilizer, a ton of which is said to sell for approximately 140 L.E.;

- Methane gas is used in cooking and as cheap fuel of cars.

4.3.3 Monkhafad Al-Qattara Project (Suggested as a Water Supply Source)

Early references and invitations to this project were first made at the beginning of the 20th century by geography professor Hans Bank from the University of Berlin in 1916. Another advocate of the idea was Professor John Boyle, from the British Royal Society, who published a study on the project in 1931 .

The project depends on diverting the course of the Nile River to pour in Monkhafad Al-Qattara instead of the sea, in order to form a fresh water lake that can act as a large water reservoir, transforming the desert area into an area of forests. The lake can also help in extending irrigation pipes to large agricultural areas. Moreover, it will be a major source of fisheries and for forming touristic areas as well as constructing large cities. The climate of the area will also change due to the water vapor rising from the lake. Companies can sell the land to obtain the value of the project (Figs. 34 and 35). 


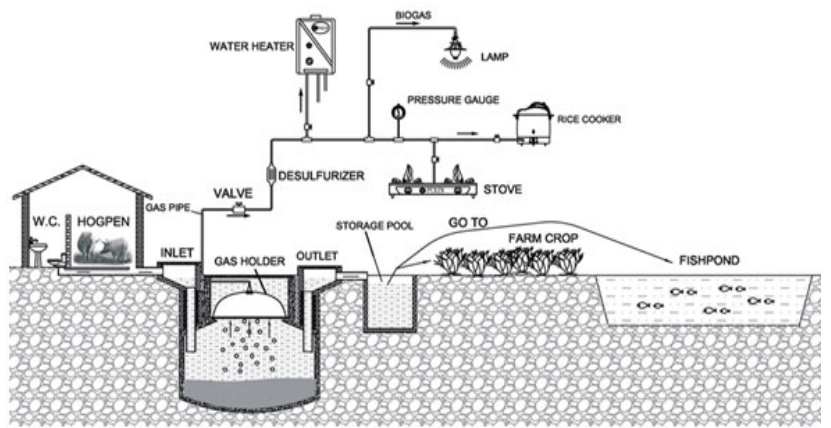

Fig. 34 As for energy supply, the project of Al-Qattara Lowland (Monkhafad Al-Qattara) is one of the national projects that solve the energy problem.

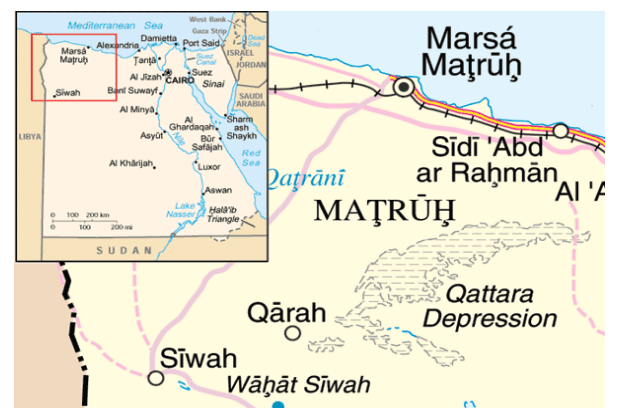

Fig. 35 Show where Monkhafad al-Qattara is.

Table 1 The solar towers in Spain and its generated energy.

\begin{tabular}{llll}
\hline Country & $\begin{array}{l}\text { Surface } \\
\text { area }\end{array}$ & $\begin{array}{l}\text { Solar tower } \\
\text { specifications }\end{array}$ & Capacity \\
\hline Spain & $74,880 \mathrm{~m}^{2}$ & $\begin{array}{l}\text { Solar towers are } \\
115 \mathrm{~m} \text { in height }\end{array}$ & $\begin{array}{l}\text { Energy is sufficient } \\
\text { for 6,000 houses at } \\
\text { capacity of } 11 \\
\text { megawatts }\end{array}$ \\
\hline
\end{tabular}

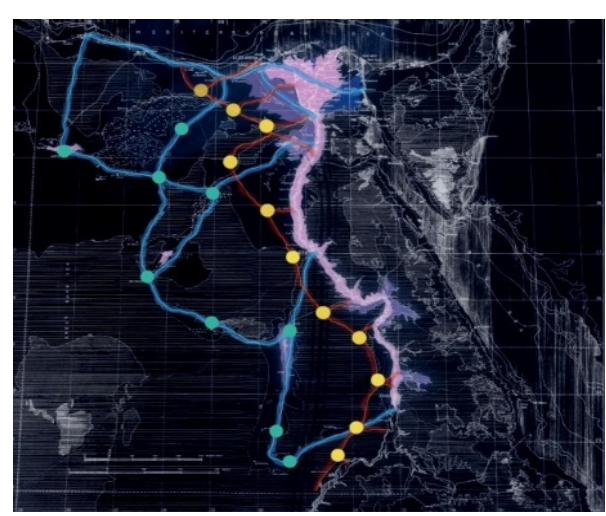

Fig. 36 Most suitable solutions.

\subsubsection{Other Ideas for the Supply of Electricity}

Project idea: The project lies close to Al-Alamein City near Marina (north coast) and can be summarized in creating a watercourse that is $75 \mathrm{~km}$ long so that the seawater can course through it to the lowland that is $145 \mathrm{~m}$ below sea level, to form an artificial lake covering an area of $12,000 \mathrm{~km}^{2}$. The flow of water can be used to generate cheap and clean electricity reaching 2,500 kW/h. This saves around 1,500 million dollars per year, which is the cost of generating electricity with fuel oil.

There are a number of advantages that give this project a high economic value, which are:

- Generating clean electricity reaching $2,500 \mathrm{~kW} / \mathrm{h}$, which saves the Egyptian treasury around 1,500 million dollars annually;

- Using rain resulting for water vapor in cultivating millions of Fadden's in the desert;

- The artificial lake can contribute to producing large amounts of salt and fish;

- Establishing a harbor so as to decrease the pressure of ships passing through the Alexandria harbor;

- Creating touristic activities;

- Housing millions of Egyptians coming from the narrow Nile Valley and creating job opportunities for them.

Large solar energy stations-(Solar Towers) Constituents (Table 1):

- Solar tower surrounded by several moving mirrors;

- Receiver (moving mirrors);

- Containers to store water vapor to use it in running the turbines that generate electricity.

Establishing solar towers to generate electricity:

- Heating the air inside the tower so that its density decreases resulting in it is rising at a very high speed. This speed can be used in running the turbines;

- The production rate of these solar towers differs depending on the surface area and height of the tower and the area for the mirrors (Fig. 36).

\section{Conclusions and Recommendations}

The author's hypothesis regarding the reallocation of people living in slums alongside the reconstruction works of the proposed development corridor suggested 
by Egyptian scientist Dr. Farouk El-Baz.

The issue of Cairo slums needs to be resolved by making a complete study for its proposed development, while bearing in mind that decreasing the population density by $40 \%$ to $60 \%$ will have a positive impact on the new designs of informally planned regions and will all provide the opportunity to accurately design them.

All Cairo slums need to be demographically studied to be able to draw a map for the new cities and for strategic projects such as agriculture, manufacture, etc...

Slums need to be divided into phases so as to make the mission of development easier when re-planning slums and designing the map of their reallocation.

When trying to re-plan the slums, two temporary camps need to be established. The first is at the site of the slum in question or very close to it. This camp will host the people of that slum until they get their new homes rebuilt.

Most suitable solutions are from the researcher's point of view: When considering the problems of slums and random areas and in attempting to resolve these problems, one must consider the ideas and major projects such as the development corridor and the Second Nile by Dr. Farouk El-Baz and Dr. Hany Al-Adl, respectively, in addition to other projects like those by Dr. Mamdouh Hamza and others.

The idea of reallocation can be considered after rehabilitating the population and developing their abilities to suit the new place to which they will move by creating national projects suitable for the abilities of the reallocated people.

Recommendations are as following a need for economic development and creating jobs in villages and rural areas to reduce migration to the city and thus reduce the growth of random areas; the need to prepare special studies on the qualifications and the productive capacities of slum dwellers. For example, the National Initiative for Human Development is to benefit from the experiences of the population of each region and the work of cooperative societies and support productivity in marketing; Relieving pressure on cities and encouraging reverse migration by making attractive development projects in the rural areas. Affirming the need to adhere to a strict imposition of laws and the need to create systems to deal with corruption and political interests. Encouraging investors to build alternatives to slum dwellers and organize promotional meetings of Arab banks and business owners to view the municipalities of the slums and the possibility of financing the development of these areas. Depending on specialized studies of slums to overcome the weak economic qualifications. Highlighting the issue in the media and working on raising awareness of citizens in the Arab world about the consequences of such a severe issue.

\section{References}

[1] The Egyptian Government Policy towards Slums Development, Cairo's Province report, Cairo Province, 2003, pp. 231-255.

[2] Egyptian Urbanism, Monitor Its Developments of Egypt Urban Space at the End of 20th Century, Survey Its Future Tracks up to 2020, Al-Maktabah Al-Academia Publishers, Cairo, Egypt, 2005.

[3] Cairo Informal Areas, Between Urban Challenges and Hidden Potentials, Facts, Voices and Visions, 2005.

[4] M. Huchzermeyer, Unlawful Occupation: Informal Settlements and Urban Policy in South Africa and Brazil, Africa World Press, Latin American Perspectives, 2004, pp. 83-106.

[5] S. Burra, Towards a pro-poor framework for slums upgrading in Mumbai, India, Environment and Urbanization 17 (1) (2005) 67-88.

[6] A Better, Investment Climate for Everyone, World development report, The World Bank, 2005.

[7] S. Tsenkova, Housing Change in Central and Eastern Europe: Integration or Fragmentation, Ashgate Publishing Limited, Aldershot, 2006, pp. 193-205.

[8] S. Tsenkova, Self-made Cities, In Search of Sustainable Solutions for Informal Settlements in the United Nations Economic Commission for Europe Regions, 2005.

[9] M. Kamal, How to Develop Informal Settlements to Achieve Sustainable Development, Egyptian National report on Informal Settlements in Cairo, Housing \& Building National Research Center, 2010, pp. 251-273. 